\title{
VARIABILITAS POLA ARUS DAN GELOMBANG DI SELAT KARIMATA
}

\author{
Aida Heriati'), Eva Mustikasari'1) \& M. Al Azhar' \\ 1)Pusat Penelitian dan Pengembangan Sumber Daya Laut dan Pesisir, Balitbang-KP, KKP \\ 2)Program Studi Oseanografi, Fakultas IImu dan Teknologi Kebumian, Institut Teknologi Bandung \\ Diterima tanggal: 20 Maret 2015; Diterima setelah perbaikan: 29 Juli 2015; Disetujui terbit tanggal 4 Nopember 2015
}

\begin{abstract}
ABSTRAK
Tulisan ini membahas mengenai kondisi parameter fisik di daerah perairan Selat Karimata, yaitu kondisi angin, kondisi pasang surut, kondisi gelombang dan kondisi arus hasil dari pemodelan oseanografi. Data yang digunakan untuk pengolahan adalah data angin dari hasil pengamatan, data pasang surut dari Tide Model Driver (TMD) dan data batimetri dari GEBCO. Kejadian angin paling dominan terjadi adalah dari arah selatan dengan persentase kejadian sebanyak 7,4\%, tenggara $6,8 \%$ dan timur 6,5\% dan hasil pemodelan gelombang menggunakan metode Sverdrup-Munk-Bretschneider memperlihatkan kondisi gelombang dengan arah gelombang dominan adalah arah tenggara dengan jumlah persentase kejadian sebesar $6,76 \%$, dengan persentase yang paling tinggi adalah pada kejadian gelombang dengan ketinggian 0,1-1 m. Pasang surut yang terjadi di Selat Karimata adalah pasang surut tipe tunggal (diurnal tides). Kondisi arus hasil pemodelan di perairan Selat Karimata menunjukkan bahwa arus yang kuat terjadi pada saat kondisi pasang dengan kecepatan maksimum arus yang terjadi adalah sebesar 0,6 m/det yang terjadi pada kondisi pasang menuju surut purnama.
\end{abstract}

Kata kunci: arus, gelombang, Selat Karimata, pasang surut

\section{ABSTRACT}

This paper discusses about the physical parameters condition in Karimata Strait, namely wind conditions, tidal conditions, wave conditions and current conditions from oceanographic modeling. The ten-year wind data derived from field observation, tidal data from Tide Model Driver (TMD) and bathimetric data from GEBCO are used for the analysis. The result shows that the most dominant wind occurs through south about $7.4 \%$, southeast $6.8 \%$ and east $6.5 \%$. Wave modeling using Sverdrup-MunkBretschneider method shows the result that dominant wave direction is toward southeast within the percentage of $6.76 \%$, the highest percentage occurs in the wave height between 0.1 to $1 \mathrm{~m}$. Type of tides in Karimata strait is categorized as diurnal tides. Current conditions modelling shows the strong currents occur in tidal conditions within a maximum speed of $0.6 \mathrm{~m} / \mathrm{sec}$ occurred at the tide to the low tide in full moon conditions.

\section{Keywords: currents, waves, Karimata Strait, tides}

\section{PENDAHULUAN}

Setiap perairan memiliki karakteristik perairan yang berbeda, baik itu disebabkan letaknya secara lintang geografis maupun akibat pengaruh-pengaruh yang terjadi di skala regional dalam perairan tersebut, baik yang mempengaruhi parameter fisik, kimia maupun biologinya. Pemahaman mengenai karakteristik suatu perairan ini diperlukan untuk mengetahui potensi dari suatu perairan tersebut sehingga pemanfaatan secara optimal dapat dilakukan dalam mengolah sumber daya alam yang ada di laut itu sendiri. Harahap \& Yanuarsyah (2012) menyebutkan bahwa Selat Karimata merupakan salah satu fishing ground yang sangat berpotensi.

Penelitian di Selat Karimata yang dilakukan oleh Prasetyo et al. (2014) melihat hubungan hasil tangkapan cumi-cumi terhadap variabel suhu permukaan laut dan klorofil-a menggunakan data satelit MODIS AQUA dan mendapatkan hasil bahwa tangkapan banyak terjadi pada musim peralihan II hingga musim barat dengan karakteristik suhu permukaan laut yang lebih tinggi pada musim barat dan sebaliknya untuk varivbel klorofil-a dimana konsentrasi yang tinggi terjadi pada musim timur.
Pengaruh musiman terjadi di daerah ini dikarenakan adanya mass air laut yang masuk dari arah utara di sekitaran Selat Karimata dan Laut Jawa. Hal ini selaras dengan penelitian yang dilakukan oleh Susanto et al. (2006) yang menyatakan bahwa Selat Karimata memiliki konsentrasi klorofil-a yang tinggi pada JuliOktober berdasarkan data citra satelit SeaWifs. Perairan Selat Karimata ini dipengaruhi oleh angin musiman dan massa air dari Samudera Hindia. (Susanto et al., 2001)

Hasil pemodelan pola arus di perairan Indonesia yang dilakukan oleh Widyastuti et al. (2010) memperlihatkan bahwa cycle rata-rata yang memiliki arus kuat terjadi di Laut Maluku dan Selat Karimata dengan kecepatan berkisar antara 800-1200 cm/det. Pemodelan arus ini menggunakan data satelit Altimetri Jason-1 yang diolah menggunakan MATLAB 8.0 selama 8 tahun (2002-2009).

Makalah ini membahas mengenai parameter fisik di perairan Selat Karimata, mengingat letak Selat Karimata ini yang strategis menghubungkan Laut Cina Selatan dengan perairan Indonesia, sehingga diduga di daerah ini arus yang terjadi juga dipengaruhi oleh arus yang terjadi di Laut Cina Selatan yang membawa 
massa air dari perairan Laut Cina Selatan ke perairan Indonesia. Hasil penelitian Susanto et al. (2013) dari data ADCP Desember 2007 sampai November 2008 melaporkan bahwa terdapat aliran pergerakan Laut Cina Selatan melalui Selat Karimata dengan aliran yang kuat menuju selatan pada musim barat dan aliran dasar yang lebih lemah di musim kemarau. Parameter fisik yang dibahas dalam tulisan ini adalah kondisi pasang surut, gelombang dan arus di perairan Selat Karimata. Kondisi ini penting untuk dipelajari dan dipahami untuk pemanfaatan sumber daya alam yang ada di dalamnya, baik sebagai sumber energi di bidang kelautan maupun sebagai faktor yang mempengaruhi migrasi ikan dalam bidang perikanan, tentunya parameter-parameter lainnya sangat diperlukan untuk memperoleh hasil yang akurat, namun pada makalah ini hanya dibatasi dalam hal parameter fisik saja.

Pemodelan oseanografi digunakan dalam skala regional untuk memperoleh gambaran secara umum mengenai kondisi gelombang dan arus di perairan Selat Karimata mengingat sulitnya memperoleh data hasil survey lapangan secara time series. Beberapa pemanfaatan akan hasil pemodelan oseanografi telah dilakukan untuk mengetahui fenomena alam yang terjadi dan kaitannya dengan sumber daya yang ada seperti yang dilakukan oleh Jumarang \& Ningsih (2013) menggunakan model numerik 3D Barotropik POM (The Princeton Ocean Model) untuk melakukan simulasi transport volume di Selat Sunda dan menghasilkan bahwa perubahan transpor volume di Selat Sunda sangat dipengaruhi oleh monsoon dibandingkan dengan pengaruh ENSO dan Dipole Model. Hal ini sesuai dengan penelitian-penelitian sebelumnya yang menyebutkan bahwa Selat Karimata yang posisinya dekat dengan Selat Sunda sangat dipengaruhi oleh monsoon.

\section{METODE PENELITIAN}

\section{Lokasi Penelitian}

Daerah penelitian adalah perairan selat Karimata yang letaknya secara geografis menghubungkan Pulau Sumatera di sebelah barat dengan Pulau Kalimantan di sebelah timurnya. Posisi koordinat dari daerah simulasi model meliputi area 101,25 - 111,30 Bujur Timur dan $11,11667^{\circ}$ Lintang Selatan sampai $0,4833^{\circ}$ Lintang Utara. Gambaran posisi selat Karimata ini dapat dilihat pada Gambar 1.

\section{Data dan Analisis}

Penelitian di perairan Selat Karimata ini menggunakan beberapa data seperti data angin yang digunakan sebagai data masukan bagi model gelombang, dan data pasang surut yang digunakan sebagai data verifikasi untuk hasil pemodelan hidrodinamika pola arus di perairan Selat Karimata.

\section{Data Angin}

Data parameter angin selama sepuluh tahun (1998 - 2007) digunakan sebagai data inputan dalam model gelombang untuk memprediksi tinggi gelombang di perairan Selat Karimata. Model gelombang yang digunakan adalah model gelombang dengan metoda Sverdrup-Munk-Bretschneider (SMB), diolah menggunakan software Fortran versi 4.0.

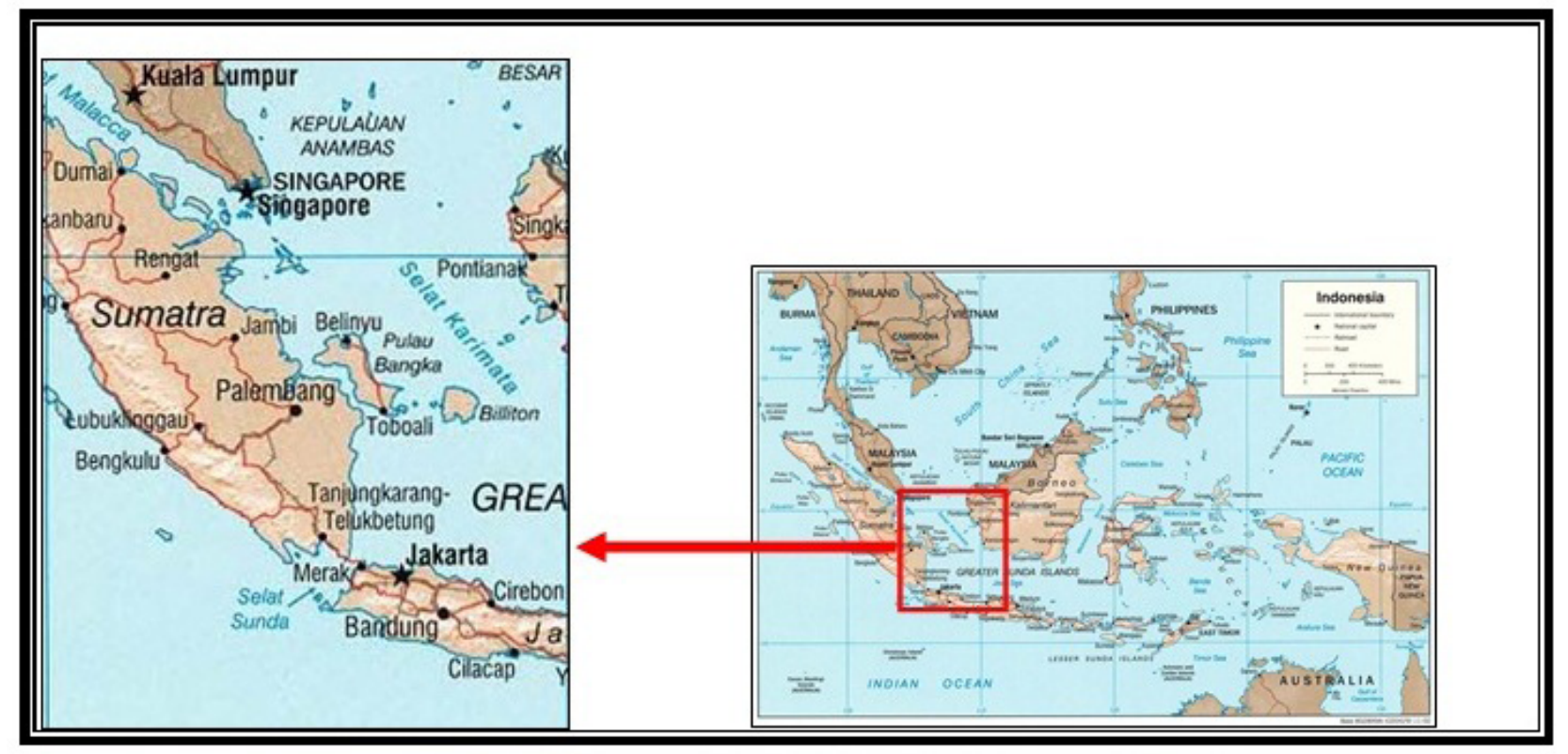

Gambar 1. Posisi Selat Karimata di Perairan Indonesia (Sumber : www.indonesia-ok.com). 
Berdasarkan data angin BMG Stasiun Meteorologi perairan Karimata dari tahun 1998 - 2007 (Tabel 1), kecepatan angin di perairan ini umumnya mencapai 4-8 knot dimana angin dari arah selatan sangat dominan, dengan persentase kejadian sebanyak 7,4 $\%$. Sementara persentase minimum dicapai oleh angin dari arah barat daya dengan persentase kejadian sebanyak $1 \%$ (Tabel 2).

\section{Data Pasang Surut}

Kondisi pasang surut suatu perairan dapat diprediksi karena sifatnya yang periodik, dengan mengetahui amplitudo dan beda fasa dari masingmasing komponen pembentuk pasang surutnya. Dapat diketahui jenis pasang surutnya dengan melakukan perhitungan terhadap bilangan Form $(F)$, bilangan Form ini diperoleh dari perhitungan : $F=(A O 1+A K 1) /$ (AM2 + AS2). Nilai prediksi pasang surut ini diperoleh dengan menggunakan software Tide Model Driver (TMD) versi 1.2. suatu model prediksi pasang surut global dan regional hasil kerja sama para peneliti di Earth \& Space Research (ESR) dengan Oregon State University (OSU) (Padman \& Erofeeva, 2003). Hasil pemodelan TMD menghasilkan nilai amplitudo dari konstanta komponen pembentuk pasang surutnya beserta tinggi muka air di perairan tersebut. Nilai Amplitudo dari masing-masing konstanta komponen pembentuk pasang surut dapat dilihat dalam Tabel 3 di bawah.

\section{Desain Model Arus}

Model hidrodinamika digunakan untuk melihat pola arus yang terjadi di daerah perairan Selat Karimata. Model hidrodinamika yang digunakan adalah Estuary and Coastal Ocean Model (ECOM) yang telah mengakomodasi penggunaan grid kurvilinier. Model ini

Tabel 1.

Jumlah Jam Kejadian Data Angin Keseluruhan Tahun 1998-2007 Stasiun Meteorologi Karimata

\begin{tabular}{lrrrrrr}
\hline Arah & \multicolumn{7}{c}{ Kecepatan (Knot) } \\
& $1-4$ & $4-8$ & $8-12$ & $12-16$ & $>16$ & Jumlah \\
\hline Utara & 100 & 397 & 241 & 61 & 12 & 811 \\
Timur Laut & 63 & 415 & 206 & 41 & 5 & 730 \\
Timur & 79 & 788 & 840 & 186 & 5 & 1.898 \\
Tenggara & 239 & 924 & 656 & 144 & 7 & 1.970 \\
Selatan & 567 & 1.449 & 117 & 6 & 3 & 2.142 \\
Barat Daya & 132 & 155 & 13 & 0 & 3 & 303 \\
Barat & 263 & 347 & 40 & 6 & 3 & 659 \\
Barat Laut & 188 & 386 & 84 & 6 & 0 & 664 \\
\hline
\end{tabular}

Jumlah Jam berangin $=9.177$

Jumlah Jam tak berangin $=19.679$

Jumlah Jam tak tercatat $=256$

Jumlah Jam kejadian TOTAL $=29.112$

Tabel 2.

Persentase Jam Kejadian Data Angin Keseluruhan Tahun 1998-2007 Stasiun Meteorologi Karimata

\begin{tabular}{lcccccr}
\hline \multirow{2}{*}{ Arah } & \multicolumn{7}{c}{ Kecepatan (Knot) } \\
& $1-4$ & $4-8$ & $8-12$ & $12-16$ & $>16$ & Jumlah (\%) \\
\hline Utara & 0,3 & 1,4 & 0,8 & 0,2 & 0,0 & 2,8 \\
Timur Laut & 0,2 & 1,4 & 0,7 & 0,1 & 0,0 & 2,5 \\
Timur & 0,3 & 2,7 & 2,9 & 0,6 & 0,0 & 6,5 \\
Tenggara & 0,8 & 3,2 & 2,3 & 0,5 & 0,0 & 6,8 \\
Selatan & 1,9 & 5,0 & 0,4 & 0,0 & 0,0 & 7,4 \\
Barat Daya & 0,5 & 0,5 & 0,0 & 0,0 & 0,0 & 1,0 \\
Barat & 0,9 & 1,2 & 0,1 & 0,0 & 0,0 & 2,3 \\
Barat Laut & 0,6 & 1,3 & 0,3 & 0,0 & 0,0 & 2,3 \\
\hline
\end{tabular}

Persentase Jam berangin $=31,5$

Persentase Jam tak berangin $=67,6$

Persentase Jam tak tercatat $=0,9$

Persentase Jam kejadian TOTAL $=100$ 
Tabel 3.

Delapan Konstanta Pembangkit Pasang Surut di Perairan Selat Karimata

\begin{tabular}{cccccc}
\hline Latitude Longitude & Parameter & Con & Ampl/MajAxis Phase(o,GMT) & MinAxis Incl(o,GMT) \\
\hline$-1,9168$ & 107,8095 & $z(m)$ & $m 2$ & 0,0341 & 330,34 \\
$-1,9168$ & 107,8095 & $z(m)$ & s2 & 0,0331 & 102,94 \\
$-1,9168$ & 107,8095 & $z(m)$ & k1 & 0,5658 & 30,77 \\
$-1,9168$ & 107,8095 & $z(m)$ & $o 1$ & 0,3968 & 331,87 \\
$-1,9168$ & 107,8095 & $z(m)$ & n2 & 0,0113 & 235,21 \\
$-1,9168$ & 107,8095 & $z(m)$ & p1 & 0,1747 & 27,24 \\
$-1,9168$ & 107,8095 & $z(m)$ & k2 & 0,0056 & 196,90 \\
$-1,9168$ & 107,8095 & $z(m)$ & q1 & 0,0712 & 317,70 \\
\hline
\end{tabular}

dikembangkan oleh HydroQual, Inc., (2002). Model ini telah banyak diterapkan di berbagai wilayah perairan, antara lain: Georges Bank (Chen \& Frank, 1997), Massachusetts Bay (Signell et al., 1996), New York Bight and New York Harbor (Blumberg et al., 1999), \& Onondaga Lake (Ahsan \& Blumburg, 1999). Pada penelitian ini, model ECOM akan diaplikasikan di sekitar perairan Selat Karimata.

Daerah simulasi model meliputi area 101,25 $111,3^{\circ}$ Bujur Timur dan $11,11667^{\circ}$ Lintang Selatan sampai $0,4833^{\circ}$ Lintang Utara. Batimetri model diperoleh dari peta digital GEBCO dengan ketelitian 1 menit. Secara horizontal, daerah model tersebut dibagi menjadi grid-grid model dengan 151 grid dalam arah sumbu $x$ dan 175 grid arah sumbu y dengan resolusi grid $\Delta \mathrm{x}=\Delta \mathrm{y}=7,4 \mathrm{~km}$. Dalam arah vertikal, sistem koordinat- $\sigma$ (sigma) dibagi menjadi 3 lapisan dimulai dari level 0,0 hingga 1,0 dengan rentang yang seragam sebesar 0,5 . Langkah waktu simulasi yang digunakan sebesar 300 detik untuk mode internal dengan faktor pengali 30 antara penghitungan mode eksternal dan internal. Dalam simulasi ini temperatur dan salinitas masih dianggap konstan secara horizontal dan vertikal.

Daerah model terdiri dari 4 batas terbuka, yaitu batas model di bagian selatan, barat, utara dan timur dengan menggunakan metode syarat batas modified Reid and Bodine (Reid \& Bodine, 1968). Elevasi pasang surut dan nilai temperatur dan salinitas yang konstan diberikan sebagai masukan di tiap batas model dalam mode diagnostik (Ezer \& Mellor, 1994). Nilai konstan temperatur dan salinitas diperoleh dari nilai rata-rata Juli berdasarkan data World Ocean Atlas 1998 yang secara spasial dirata-ratakan untuk daerah cakupan model. Nilai temperatur dan salinitas tersebut dirata-ratakan terhadap kedalaman sehingga berkisar masing-masing antara $28 \mathrm{C}$ dan 36 psu. Data pasang surut diberikan dengan memasukkan konstanta harmonik berupa amplitudo dan fasa 8 komponen pasang surut yang diperoleh dari pemodelan pasang surut menggunakan perangkat lunak Tidal Model Driver (TMD) (Padman \& Erofeeva, 2003) yang mempunyai resolusi spasial $1 / 6$ derajat (Table 3 ). Data konstanta harmonik pasang surut diberikan di setiap titik batas terbuka model. Koefisien gesekan minimum (CD) diberikan sebesar $3 \times 10^{-3}$ dan Bottom roughness length $\left(Z_{o b}\right)$ ditentukan sebesar $3 \mathrm{~cm}$. Konstanta percampuran horizontal yang digunakan adalah 0,1 dan konstanta percampuran vertikal sebesar 1,0 × 10-6. Konstanta ini dipilih untuk merepresentasikan percampuran horizontal dan vertikal di perairan dangkal seperti Selat Karimata (Blumberg \& Krone, 2002).

Model hidrodinamika ini disimulasikan selama 15 hari, yaitu dari tanggal 12 hingga 26 Juli 2008 dengan mengasumsikan bahwa temperatur dan salinitas adalah konstan sehingga arus yang mengalir utamanya dipengaruhi oleh perbedaan elevasi pasang surut.

\section{HASIL DAN PEMBAHASAN}

\section{Gelombang di Selat Karimata}

Data parameter angin selama sepuluh tahun (1998 - 2007) digunakan sebagai data input dalam model gelombang, dari hasil pemodelan diperoleh informasi kondisi gelombang di perairan ini relatif normal dengan ketinggian berkisar antara 0,1 $2 \mathrm{~m}$. Gelombang yang paling sering terjadi adalah gelombang arah tenggara dengan jumlah persentase kejadian sebesar $6,76 \%$, Persentase yang paling tinggi adalah $6,64 \%$ dengan ketinggian antara 0,1-1 m, sementara gelombang dengan ketinggian antara $1-2$ $\mathrm{m}$ persentasenya sebesar $0,12 \%$ (Tabel 4 ). Persentase kejadian gelombang yang paling sedikit terjadi pada arah timur laut dengan persentase $2,51 \%$. Persentase kejadian angin dan gelombang dapat pula dilihat dari windrose \& waverose pada Gambar 2 dan 3.

\section{Pasang Surut di Selat Karimata}

Bilangan Form digunakan untuk mengetahui karakteristik pasang surut suatu perairan. Dari hasil perhitungan bilangan Form di perairan Selat Karimata diperoleh besar bilangan Form $(F)=14,3244 \approx 14$ untuk perairan Selat Karimata. Dari hasil bilangan Form tersebut karakteristik pasang surut di perairan selat Karimata secara umum adalah jenis pasang surut tipe tunggal (diurnal tides) yaitu nilai bilangan Form yang 


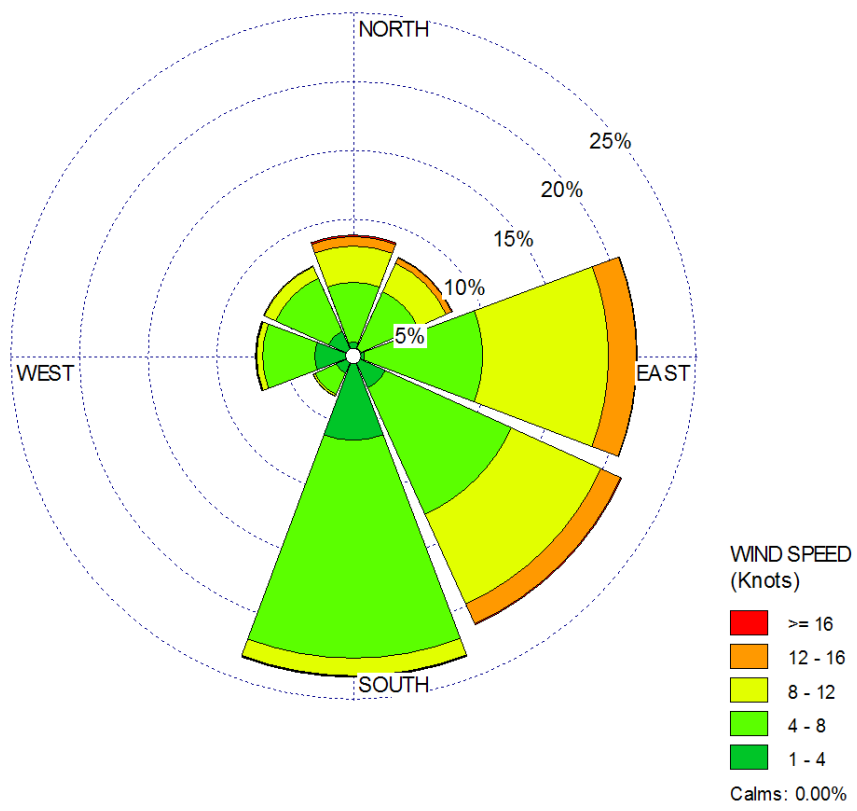

Gambar 2. Persentase kejadian angin Tahun 1998-2007.

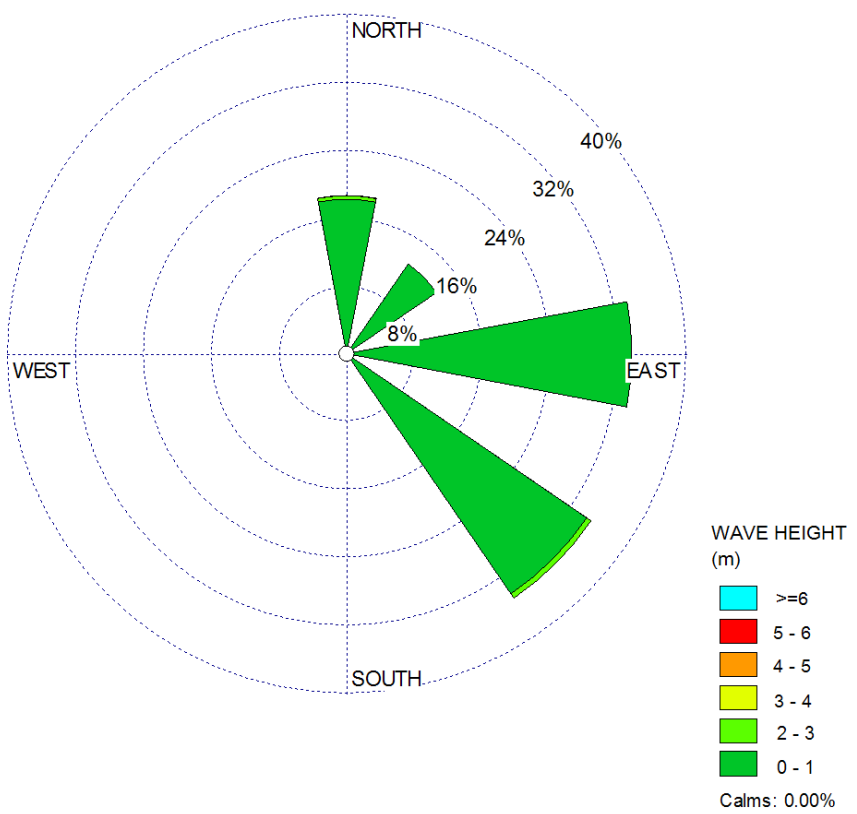

Gambar 3. Persentase prakiraan gelombang hasil model SMB Tahun 1998-2007.

diperoleh adalah $\mathrm{F}>3$.

Hal ini menunjukkan bahwa dalam satu hari terjadi 1 kali pasang dan 1 kali surut, fenomena ini dapat dilihat pada gambar hasil prediksi 24 jam di Selat Karimata (Gambar 4).

\section{Verifikasi Hasil Pemodelan}

Dari hasil pemodelan hidrodinamika yang dilakukan, verifikasi hasil simulasi elevasi muka air dilakukan terhadap data pasang surut global OSU tidal inversion pada 12 - 26 Juli 2008. Lokasi verifikasi berada di titik 104,87 BT dan 1,38 LS. Hasil verifikasi memperlihatkan bahwa elevasi hasil simulasi bersesuaian dengan data pasang surut global dengan koefisien korelasi sebesar 0,96 (Gambar 5), yang artinya korelasi sangat tinggi secara fase atau dapat pula diartikan bahwa tidak ada perbedaan fase antara pasut simulasi model ECOM dengan OSU. Kesalahan 
Tabel 4.

Persentase Kejadian Gelombang hasil model SMB Secara Total Tahun 1998-2007 Stasiun Meteorologi Karimata

\begin{tabular}{lllllll}
\hline Arah & \multicolumn{7}{c}{ Tinggi Gelombang } & & \\
& $0,1-1,0$ & $1,0-2,0$ & $2,0-3,0$ & $3,0-4,0$ & $>5,0$ & Jumlah \\
\hline Utara & 3,53 & 0,08 & 0,00 & 0,00 & 0,01 & 3,62 \\
Timur Laut & 2,50 & 0,00 & 0,00 & 0,00 & 0,00 & 2,51 \\
Timur & 6,51 & 0,00 & 0,00 & 0,00 & 0,00 & 6,52 \\
Tenggara & 6,64 & 0,12 & 0,00 & 0,00 & 0,00 & 6,76 \\
\hline & Jumlah & & & & 19,41 \\
\hline
\end{tabular}

Persentase kejadian gelombang akibat angin : 19,41 Persentase kejadian tidak ada gelombang akibat angin : 80,59

Persentase kejadian tidak ada gelombang akibat angin : 0,00

Persentase kejadian total : 100,00

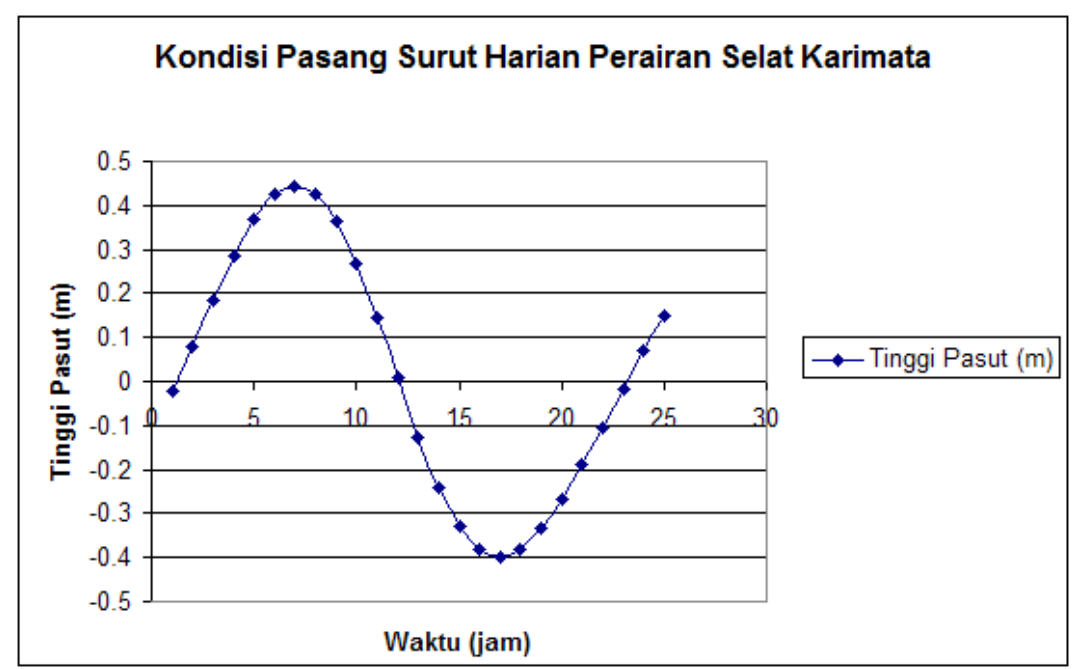

Gambar 4. Kondisi Pasang Surut Perairan Selat Karimata.

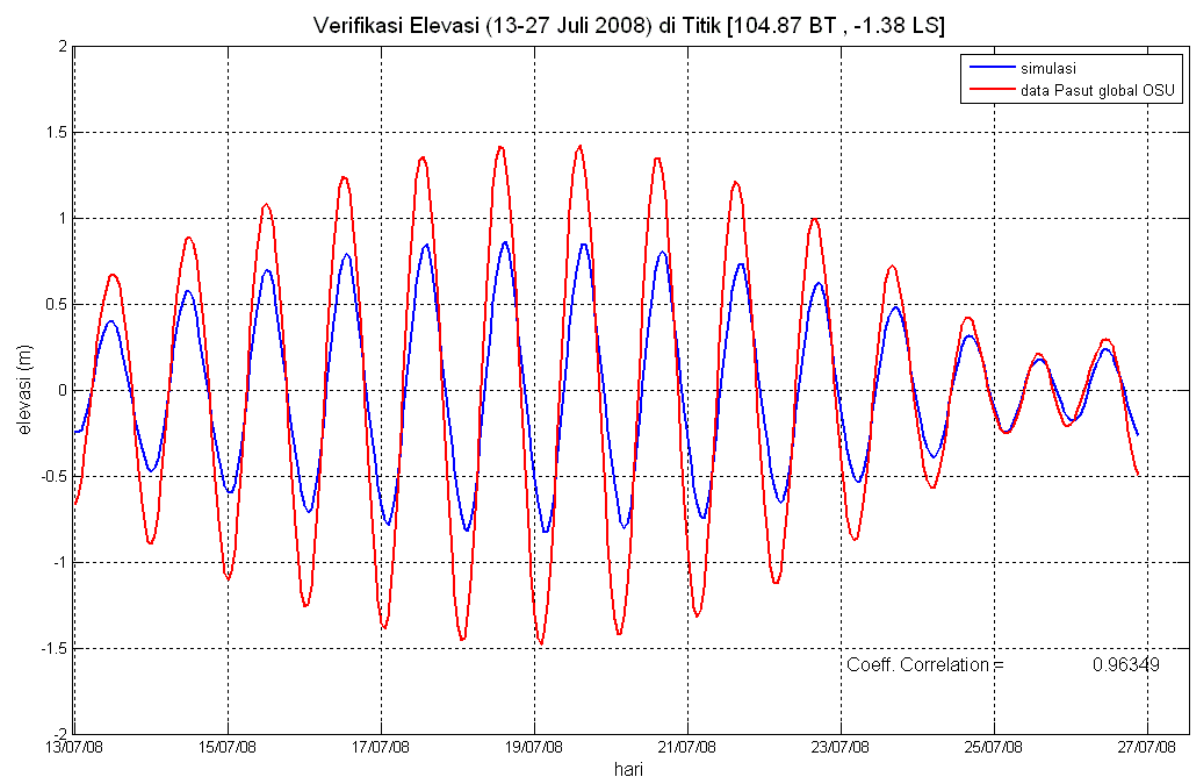

Gambar 5. Verifikasi elevasi hasil simulasi pada tanggal 13-27 Juli 2008. 
model dihitung menggunakan Mean Absolute Error (MAE) dan diperoleh hasil sebesar 0,19 m, hal ini menunjukkan bahwa hasil model cukup baik dalam mensimulasikan pola evelasi pasang surut di Selat Karimata.

\section{Pola Arus di Selat Karimata}

Hasil pemodelan hidrodinamika arus menunjukkan kondisi arus dan elevasi sebagai berikut:

- $\quad$ Pada Kondisi Surut menuju Pasang Purnama

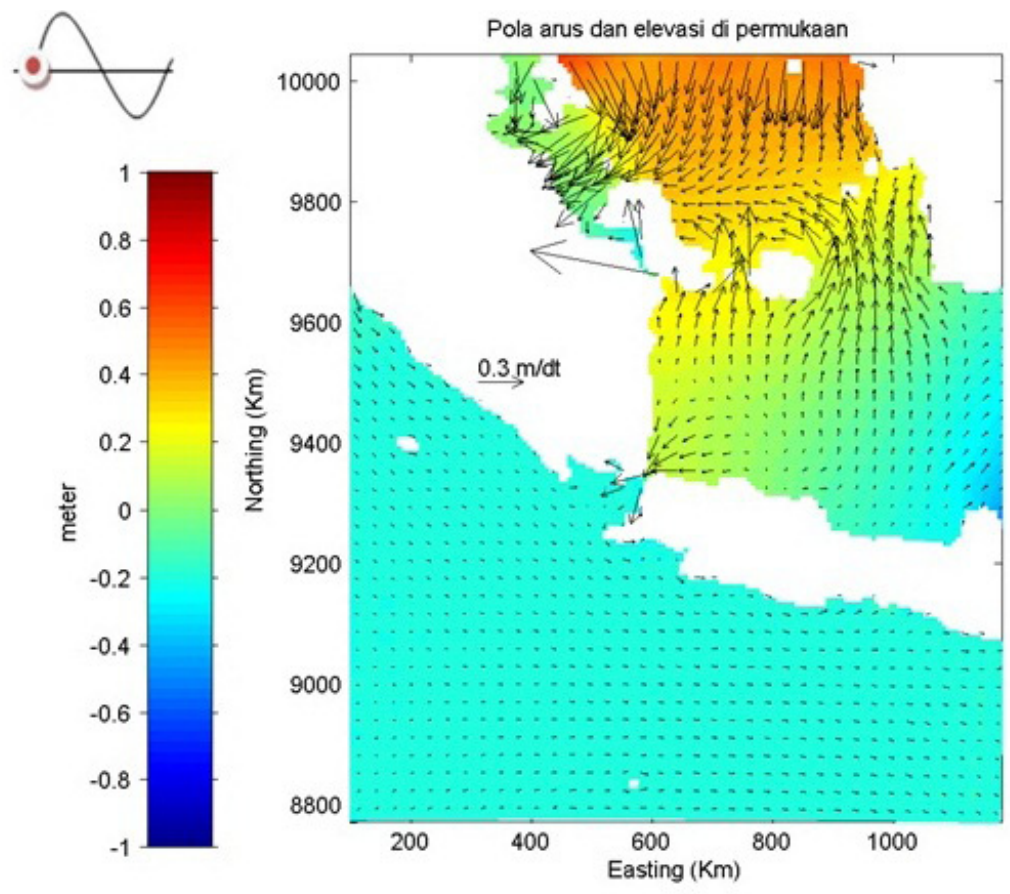

Gambar 6. Pola arus dan elevasi di permukaan saat surut menuju pasang purnama.

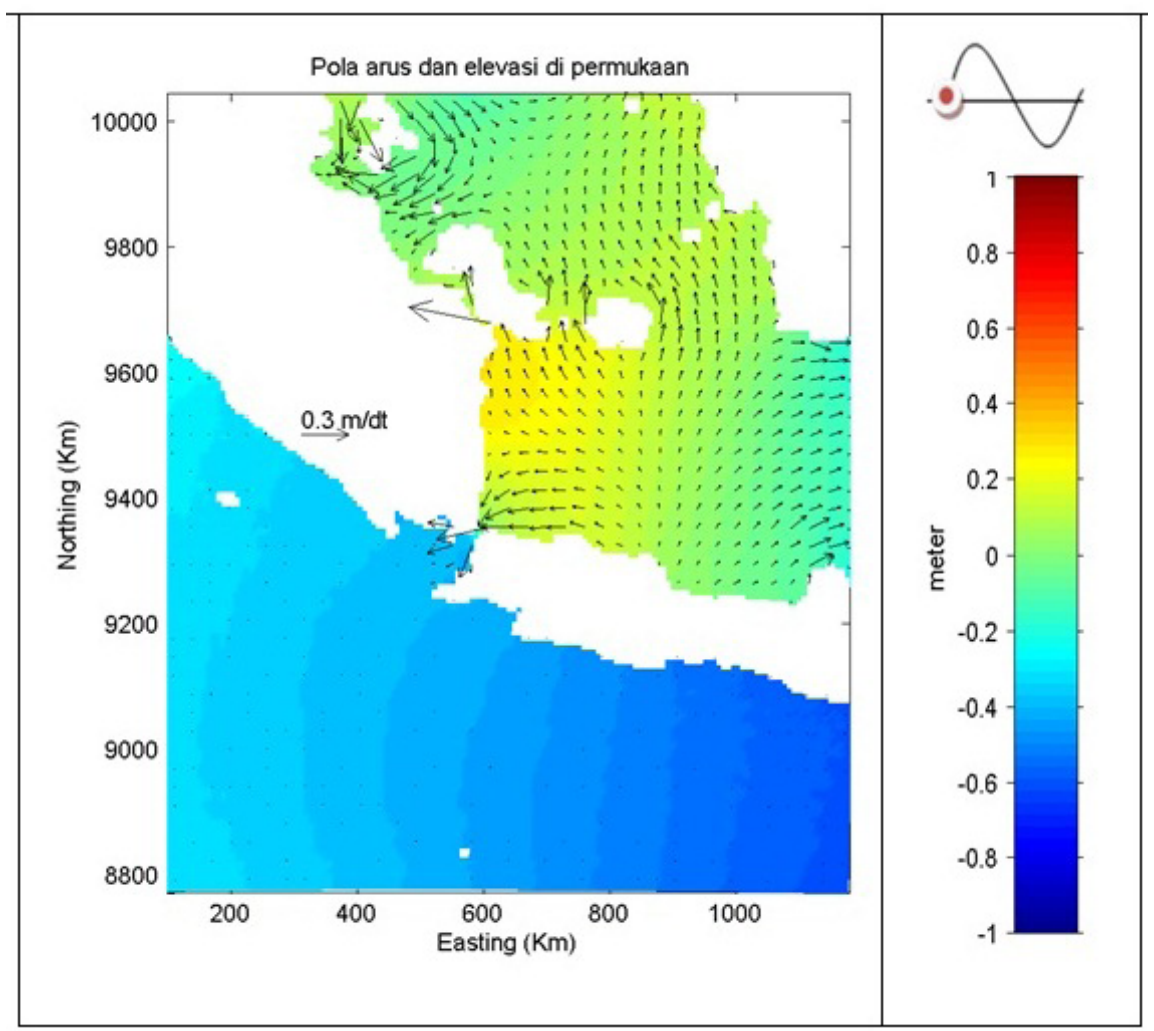

Gambar 7. Pola arus dan elevasi di permukaan saat surut menuju pasang perbani. 
Kecepatan arus maksimum mencapai 0,5 m/det pada saat surut menuju pasang purnama (Gambar6) dan melemah pada saat pasang perbani menjadi sekitar 0,3 m/det (Gambar 7). Kecepatan maksimum terlihat di daerah-daerah dengan geometri yang sempit, yaitu di selat-selat kecil di sekitar Selat Karimata dan di Selat Sunda. Arus mengalir ke arah utara dari Laut Jawa memasuki Selat Karimata dan ke arah barat daya melewati Selat Sunda menuju ke Samudera Hindia , sedangkan dari Laut Cina Selatan arus juga bergerak ke arah selatan memasuki Selat Karimata, kondisi ini terjadi pada saat surut menuju pasang purnama, menurut Fang et al (2009) diperkirakan pada
Juli ini terdapat sekitar 1.16Sv volume transport yang terbawa dari Selat Karimata menuju ke Laut Jawa dan bergabung dengan Arus Lintas Indonesia (ITF).

Pada saat surut menuju pasang perbani terlihat adanya pergerakan arus ke arah timur seperti yang terjadi di Laut Jawa dan adanya pergerakan arus yang masuk dari Laut Cina Selatan di sebelah barat perairan dan kembali ke bergerak ke arah Laut Cina Selatan di sebelah timur perairan Selat Karimata.

Elevasi pada kondisi surut menuju pasang purnama mencapai 0,6 m (Gambar 6) sedangkan

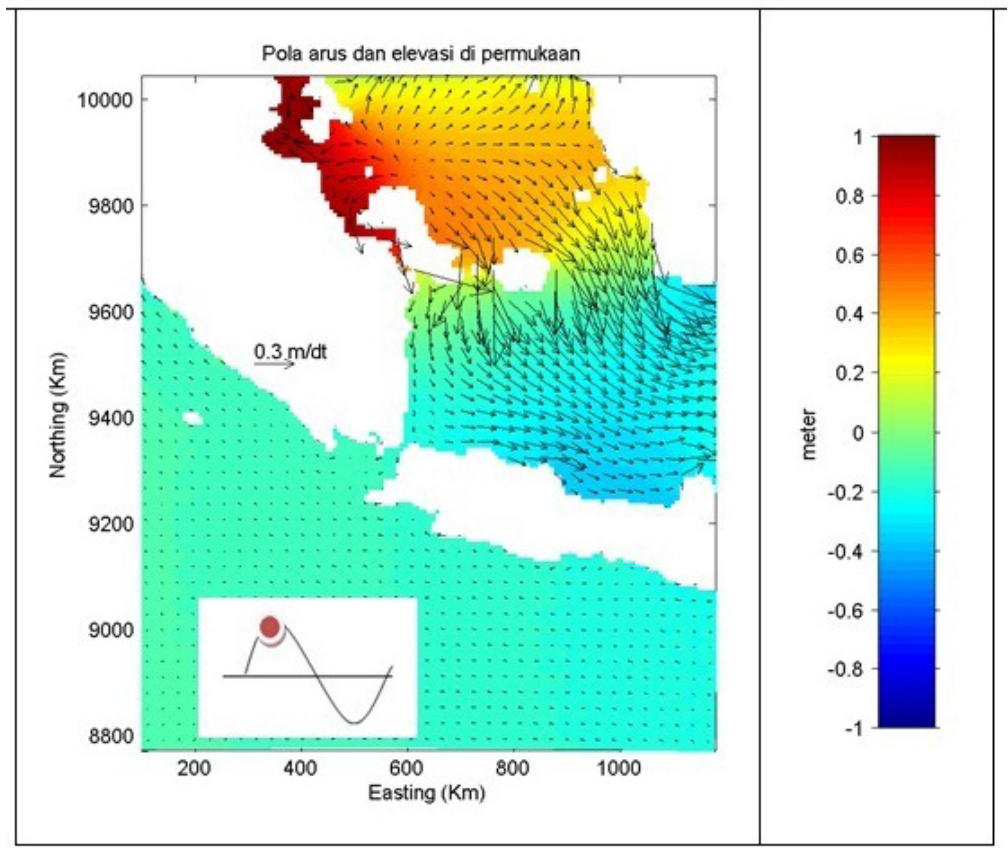

Gambar 8. Pola arus dan elevasi di permukaan saat pasang tertinggi purnama.

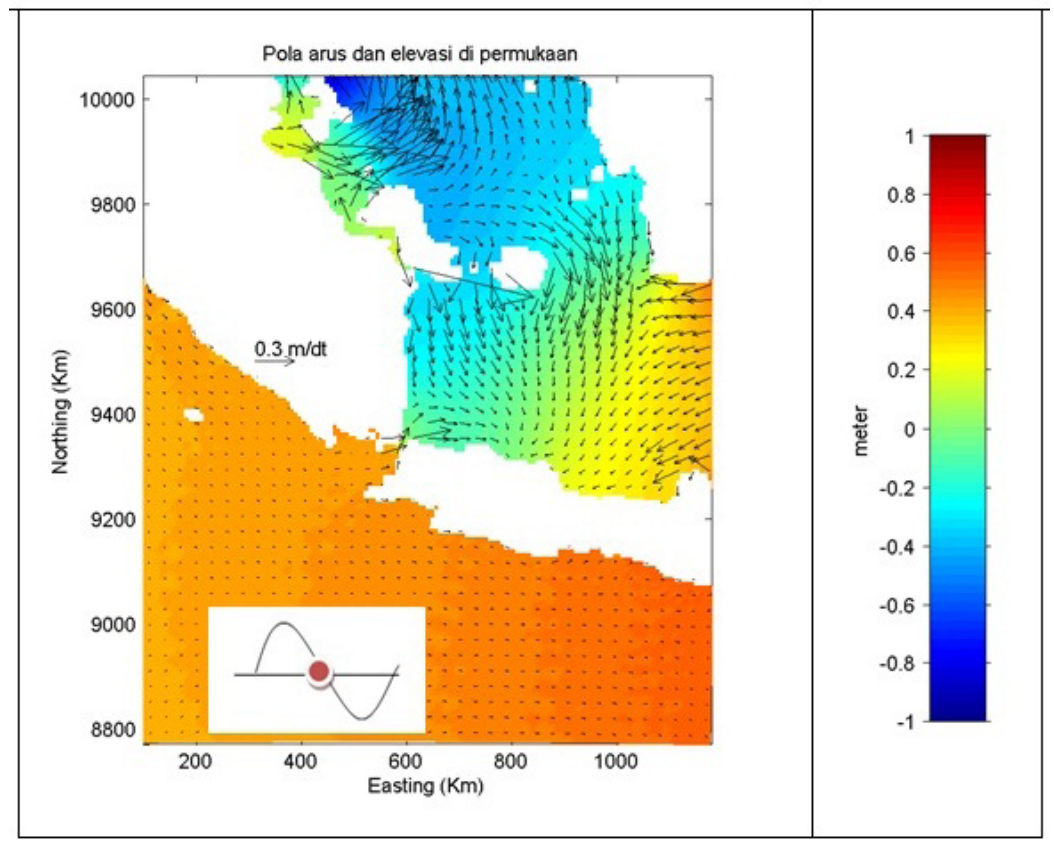

Gambar 9. Pola arus dan elevasi di permukaan saat pasang tertinggi perbani. 
pada kondisi surut menuju pasang perbani elevasi maksimum hanya mencapai $0,3 \mathrm{~m}$ (Gambar 7). Kondisi umum elevasi di Selat Karimata lebih tinggi bila dibandingkan dengan elevasi di Samudera Hindia pada saat kondisi surut menuju pasang.

\section{- Pada Kondisi Pasang tertinggi}

Arus maksimum mencapai $0,5 \mathrm{~m} / \mathrm{det}$ pada saat pasang tertinggi purnama dan arus mengalir ke arah timur memasuki Laut Jawa dari Selat Karimata. Arus maksimum terlihat di sepanjang Selat Karimata dan Laut Jawa (Gambar 8). Pada kondisi pasang perbani, arus yang mengalir menjadi lebih kecil karena perbedaan elevasi yang makin kecil pula (Gambar 9). Sedikit perbedaan yang terjadi pada kondisi purnama dan perbani adalah pada kondisi pasang tertinggi purnama arus bergerak ke arah timur laut memasuki Laut Cina Selatan, sedangkan pada kondisi pasang tertinggi perbani arus bergerak ke arah barat laut memasuki Laut Cina Selatan. Hal ini sesuai dengan yang dikemukakan oleh Fang et al. (2009) bahwa pada musim panas (Juli), sirkulasi interocean terlihat dengan adanya pergerakan arus dari Selat Karimata yang bergerak kearah utara-timur laut menuju Selat Taiwan dan Selat Luzon.

Elevasi maksimum saat pasang tertinggi

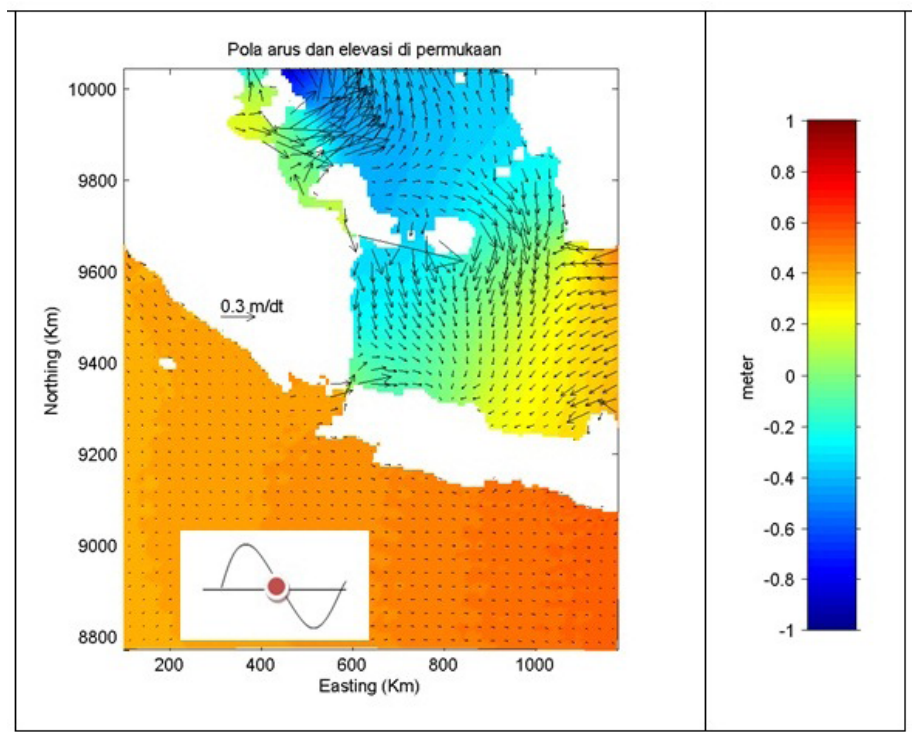

Gambar 10. Pola arus dan elevasi di permukaan saat pasang menuju surut purnama.

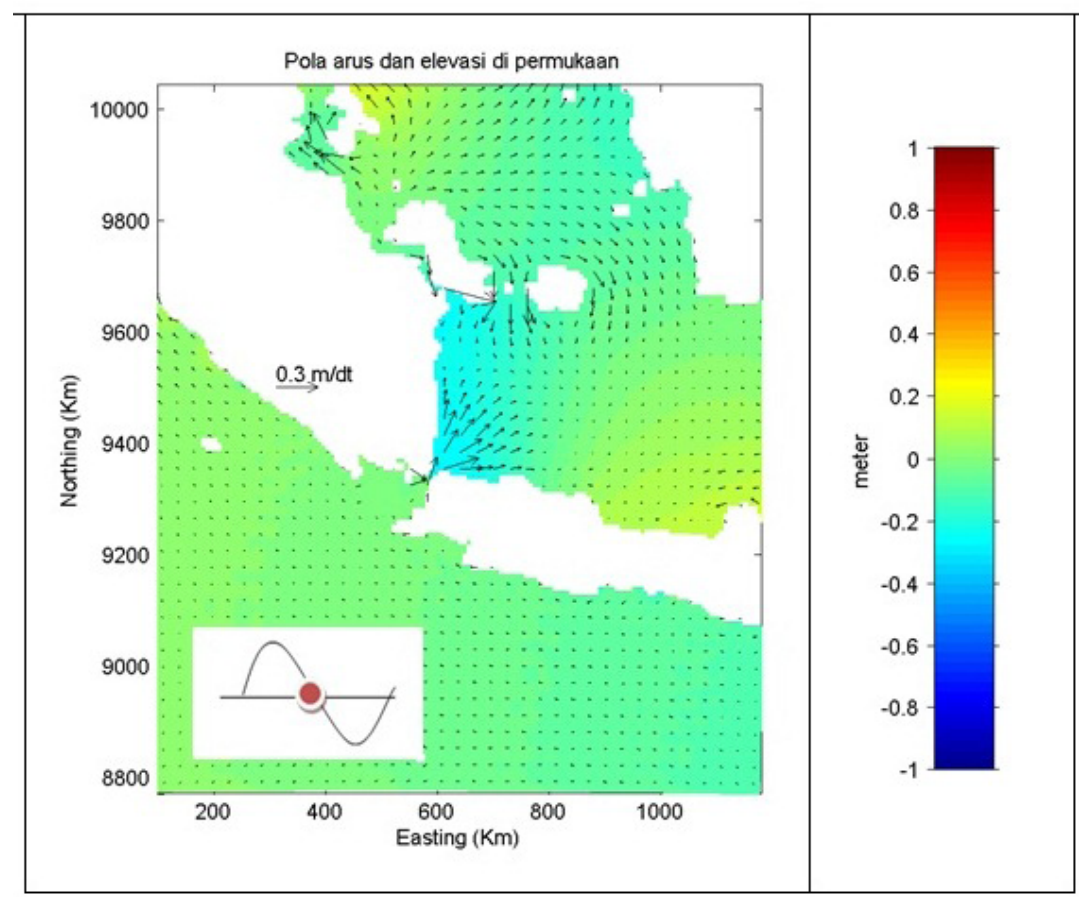

Gambar 11. Pola arus dan elevasi di permukaan saat pasang menuju surut perbani. 


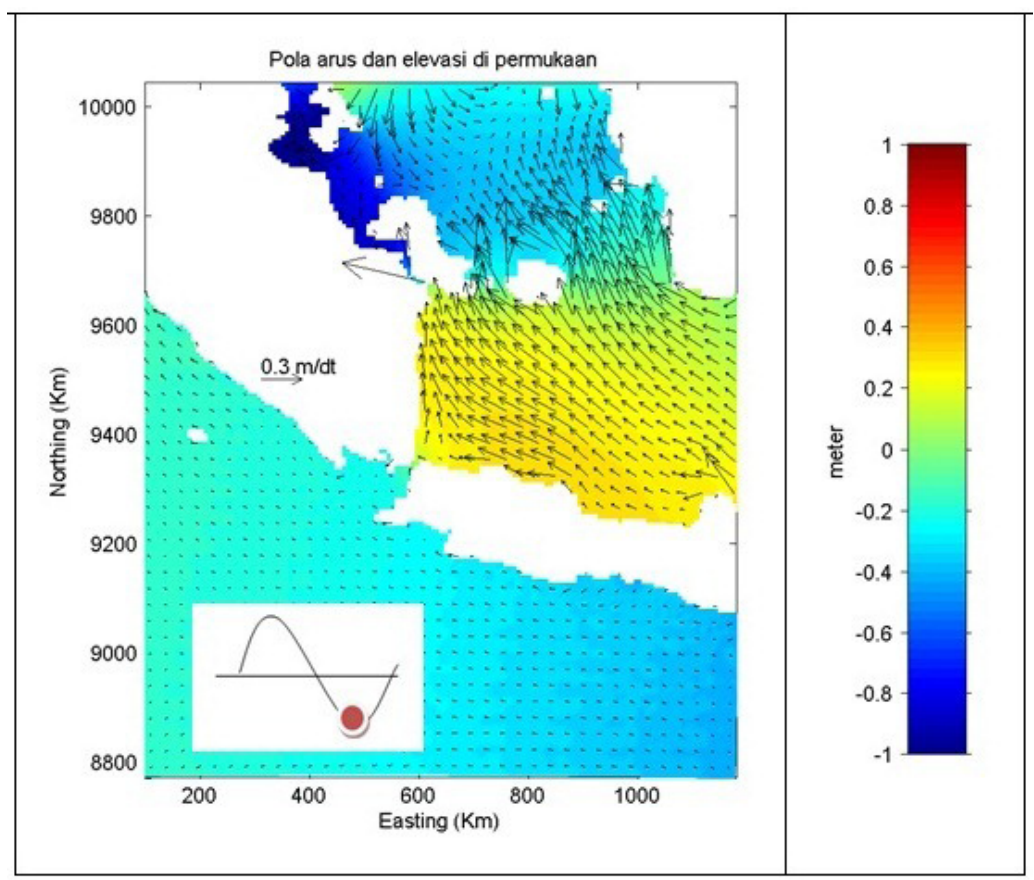

Gambar 12. Pola arus dan elevasi di permukaan saat surut terendah purnama.

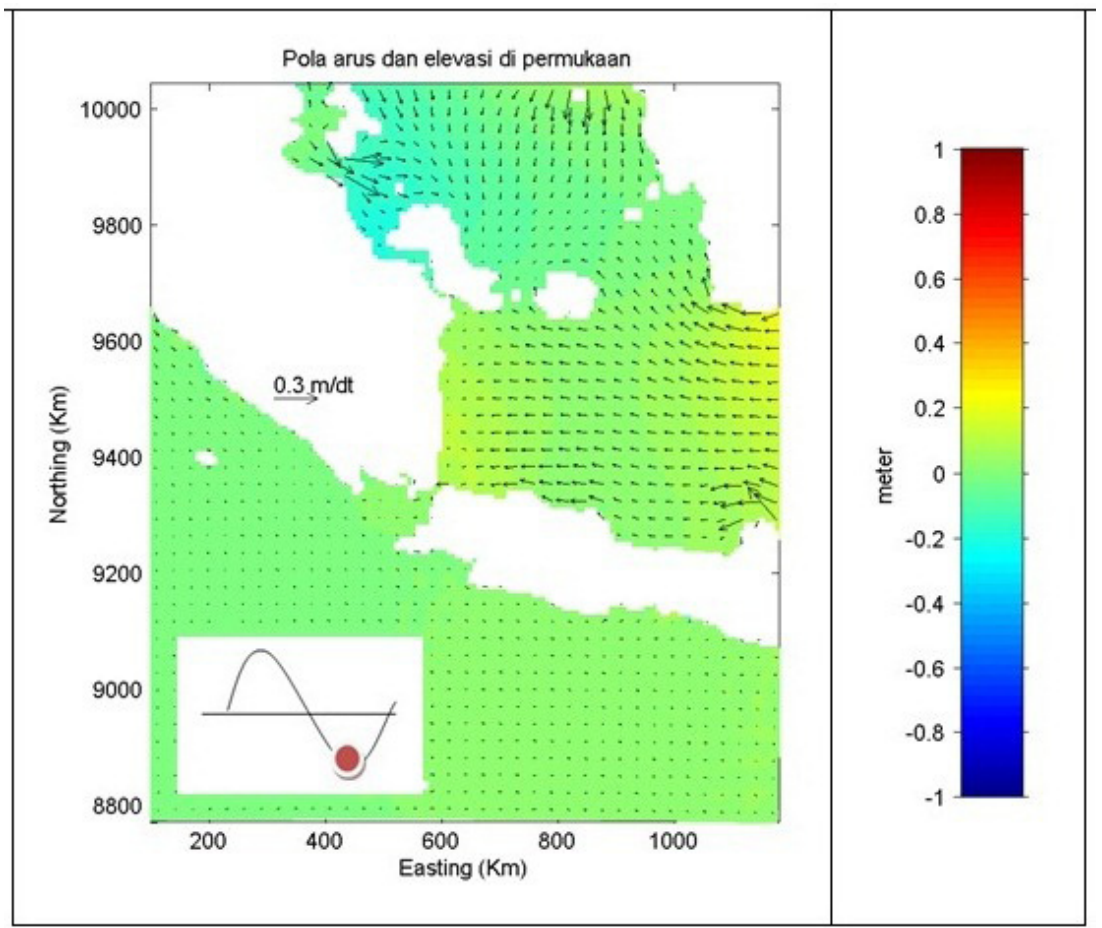

Gambar 13. Pola arus dan elevasi di permukaan saat surut terendah purnama.

purnama mencapai $1 \mathrm{~m}$ yang terjadi di sebelah timur Selat Karimata yaitu di Selat Berhala (Gambar 8). Kondisi umum elevasi yang terjadi pada kondisi pasang tertinggi purnama adalah elevasi di perairan Samudera lebih rendah dibandingkan dengan elevasi permukaan di perairan Selat Karimata, sedangkan kejadian sebaliknya terjadi pada kondisi pasang tertinggi perbani (Gambar 9).

- Pada Kondisi Pasang menuju surut
Arus mengalir maksimum mencapai $0,6 \mathrm{~m} /$ det pada saat pasang menuju surut purnama dan mengalir berkebalikan dengan saat surut menuju pasang (Gambar 10). Pada kondisi pasang perbani, arus yang mengalir mengecil dengan arah yang sama seperti saat kondisi pasang purnama (Gambar 11). Arus di Selat Karimata bergerak menuju Laut Cina Selatan dan Laut Jawa dan terlihat pula pergerakan arus memasuki Selat Sunda menuju Laut Jawa pada kondisi pasang 
menuju surut perbani terlihat arus dengan kecepatan yang besar di daerah-daerah dengan geometri sempit, yaitu daerah-daerah selat seperti Selat Sunda dan Selat Berhala. Penelitian dari Fang et al. (2012) menyebutkan bahwa mulai Juni terlihat pergerakan arus dari Selat Karimata menuju Laut Cina Selatan sampai garis pantai Vietnam $(110 \mathrm{~N})$, aliran ini cukup kuat dan stabil.

Gambar 10 menunjukkan kondisi pasang menuju surut, dimana terlihat elevasi yang sangat bervariasi pada saat purnama dengan elevasi yang lebih tinggi di perairan Samudera Hindia dibandingkan perairan Selat Karimata dan Laut Jawa.

Elevasi maksimum terjadi di perairan sebelah timur model, yaitu mencapai $0,6 \mathrm{~m}$ di perairan Samudera Hindia dan 0,4 m di perairan Laut Jawa.

\section{- Pada Kondisi Surut terendah}

Kecepatan arus mengalir maksimum pada kondisi surut terendah saat pasang purnama mencapai 0,5 m/det dan umumnya mengalir dari Laut jawa ke arah utara memasuki Selat Karimata dan memasuki Samudera Hindia melalui Selat Sunda (Gambar 12) terlihat pula adanya pergerakan arus yang memasuki Selat Karimata dari Laut Cina Selatan. Sedangkan, pada saat surut terendah perbani, arus menjadi lebih kecil dan mengalir sama dengan saat kondisi pasang purnama (Gambar 13). Hal ini sesuai dengan hasil penelitian Fang et al. (2009) dan Wyrtki (1961) dimana transport di Selat Karimata bergerak ke arah selatan pada Oktober-Mei dan arah sebaliknya pada JuniSeptember. Qu et al. (2005) menyatakan bahwa aliran yang melalui Selat Karimata lebih besar dibandingkan dengan aliran transport di Selat Mindoro.

Hal ini menyatakan bahwa Selat Karimata ini memiliki peran yang besar dalam menghantarkan pengaruh dari Samudera Pasifik, namun bukan satusatunya jalan.

Elevasi minimum mencapai $1 \mathrm{~m}$ di bawah permukaan air terlihat di perairan Selat Berhala dan secara umum kondisi elevasi di perairan Samudera Hindia lebih rendah dibandingkan elevasi di perairan Selat Karimata dan Laut jawa. Perbedaan elevasi yang tinggi pada saat surut terendah purnama menyebabkan arus yang terjadi pada kondisi tersebut lebih besar dibandingkan arus yang terjadi pada saat kondisi surut terendah perbani.

\section{KESIMPULAN}

Berdasarkan hasil pengolahan data-data fisik di perairan Selat Karimata diperoleh bahwa dari data kondisi angin selama 10 tahun pengamatan, kejadian angin paling dominan terjadi adalah dari arah selatan dengan porsentase kejadian sebanyak 7,4\%, tenggara $6,8 \%$ dan timur $6,5 \%$ dengan besar kecepatannya berkisar antara 4 - 8 knot.

- Hasil pemodelan gelombang memperlihatkan kondisi gelombang dengan kisaran tinggi gelombang sebesar 0,1-2 $\mathrm{m}$ dan arah penjalaran gelombang dominan adalah arah tenggara dengan jumlah prosentase kejadian sebesar 6,76 $\%$, dengan prosentase yang paling tinggi adalah pada kejadian gelombang dengan ketinggian 0,1 $-1 \mathrm{~m}$.

- $\quad$ Tipe pasang surut yang terjadi di Selat Karimata adalah tipe pasang surut tipe tunggal (diurnal tides) diperoleh dari hasil perhitungan bilangan Form dan dilihat pula dari hasil prediksi kejadian pasang surutnya selama satu siklus pasang surut.

- Kondisi arus hasil pemodelan di perairan Selat Karimata ini menunjukkan bahwa arus yang kuat terjadi pada saat kondisi pasang dengan kecepatan maksimum arus yang terjadi adalah sebesar 0,6 m/dtk yang terjadi pada kondisi pasang menuju surut purnama.

- Pengamatan lebih lanjut perlu dilakukan untuk memperoleh hasil yang akurat dari hasil pemodelan yang dilakukan dari penelitian ini. Validasi model dapat dilakukan dari data-data hasil survey yang telah dilakukan sehingga dapat memberikan kesesuaian dan koreksi terhadap hasil pemodelan.

\section{PERSANTUNAN}

Penelitian ini dilaksanakan dengan menggunakan DIPAPusat Penelitan dan Pengembangan Sumberdaya Laut dan Pesisir (P3SDLP), Kementerian Kelautan dan Perikanan Tahun 2009, kemudian dilanjutkan dengan reanalisis data, pemodelan serta penyusunan artikel menggunakan DIPA P3SDLP Tahun 2015. Penulis mengucapkan terima kasih kepada bapak Budi Sulistyo selaku Kepala Pusat Penelitian dan Pengembangan Sumberdaya Laut dan Pesisir atas dukungannya dalam menyelesaikan tulisan ini serta pihak lainnya yang tidak dapat disebutkan satu persatu.

\section{DAFTAR PUSTAKA}

Ahsan, A. K. M. Q. \& Blumberg, A. F. (1999). Threedimensional hydrothermal model of Onondaga Lake, New York. J. Hyd. Eng.,

Blumberg, A. F. \& Krone R. B. (2002). ECOMSED Manual[M]. New York : Academic Press.

Blumberg, A.F., L.A. Khan \& John, J.P. St. (1999). Three-dimensional hydrodynamic model of New York Harbor Region. J. Hydr. Engr. ASCE. 
Chen, C. \& Franks, P. J. S. (1997). A Coupled Biological and Physical Model of Georges Bank. Report of the 2nd international GLOBEC modeling conference, Nantes, France, 1995.

Ezer, T. \& Mellor, G. L.(1994). Diagnostic and Prognostic Calculations of the North Atlantic Circulation and Sea Level using a Sigma Coordinate Ocean Model. J. Geophys. Res. (99): 14159- 14171.

Fang, G., Wang, Y., Wei, Z., Fang, Y., Qiao, F., \& $\mathrm{Hu}, \mathrm{X}$. (2009). Interocean Circulation and Heat and Freshwater Budgets of The South China Sea based on Numerical Model. Dynamics of Atmospheres and Ocean (47): 55-72. Elsevier.

Fang, G., Wang, G., Fang, Y., \& Fang, W. (2012). A review on The South China Sea Western Boundary Current. Acta Oceanol. Sin. 31(5):1-10.

Harahap, S. A. \& Yanuarsyah, I. (2012). Aplikasi Sistem Informasi Geografis (SIG) untuk Zonasi Jalur Penangkapan Ikan di Perairan Kalimantan Barat. Jurnal Akuatika 3(1):40-48.

HydroQual, Inc. (2002). A water quality model for Jamaica Bay: Calibration of the Jamaica Bay Eutrophication Model (JEM). Prepared for the NYCDEP under subcontract to O'Brien and Gere Engineers, Inc. Mahwah, NJ.

Jumarang, M. I. \& Ningsih, N. S. (2013). Transpor Volume Massa Air di Selat Sunda Akibat Interaksi Enso, Monsun dan Dipole Mode. Prosiding Semirata FMIPA Universitas lampung. Lampung: 409-415.

Padman, L. \& Erofeeva, S. (2003). Tide Model Driver (TMD) Manual. Earth \& Space Research

Prasetyo, B. A., Hutabarat, S., \& Hartoko, A. (2014). Sebaran Spasial Cumi-cumi (Loligo Spp.) dengan Variabel Suhu Permukaan Laut dan Klorofil-a Data Satelit Modis Aqua di Selat Karimata hingga Laut Jawa. Diponegoro Journal of Maquares (Management of Aquatic Resources) 3(1):51-60.

Qu, T., Du, Y., Meyers, G., Ishida, A., \& Wang, D. (2005). Connecting the Tropical Pacific with Indian Ocean through South China Sea. Geophysical Research Letters (32).

Reid, R.O. \& Bodine, B.R. (1968). Numerical model for storm surges in Galveston Bay: Reston, Virginia, National American Society of Civil Engineers, Journal of the Waterways and Harbors Division, v. 94, no. WWI:.33-57.
Signell, R.P., Jenter, H. L. \& Blumberg, A.F. (1996). Circulation and effluent dilution modeling in Massachusetts Bay: model implementation, verification and results. Open-File Report 96-015, U.S. Geological Survey.

Susanto, R.D., Gordon, A.L. \& Zeng. Q. (2001). Upwelling Along the Coasts of Java and Sumatera and its Relation to ENSO. Geophysical Research Letters. 28:1.559-1.602.

Susanto, R.D., Moore II, T. S. \& Marra. J. (2006). Ocean Color Variablity in the Indonesian Sea During the Sea WiFS Era. Geochem., Geophys., Geosyst. 7 (5):1525-1541.

Susanto, D., Wei, Z., Adi. T.R., Fan, B., Li, S., \& Fang, G. (2013). Observation of the Karimata Strait througflow from December 2007 to November 2008. Acta Oceanol Sin. 32(5):1-6.

Widyastuti, R., Handoko, E.Y., \& Suntoyo. (2010). Pemodelan Pola Arus Laut Permukaan di Perairan Indonesia Menggunakan Data Satelit Altimetri Jason-1. Tugas Akhir Program Studi Geomatika. Fakultas Teknik Sipil dan Perencanaan. Institut Teknologi Sepuluh Nopember. Surabaya.

Wyrtki, K. (1961). Physical Oceanography of Southeast Asian Waters. Scripps Institute of Oceanography, Naga Re. 2, La Jolla, Calif.

http://www.indonesia-ok.com/images/peta $\% 20$ indonesia_rel_2002.jpg. Akses tanggal 20 Oktober 2005 